\title{
Broad spectrum antimicrobial activities from spore-forming bacteria isolated from the Vietnam Sea
}

\author{
Chau Minh Khanh ${ }^{1,2}$, Dong Van Quyen ${ }^{\text {Corresp., } 3}$, Joshua M Fraser ${ }^{1}$, Andrew T Smith ${ }^{4}$, Thi Thu Hao Van ${ }^{1}$, Robert J \\ Moore ${ }^{\text {Corresp. } 1}$ \\ ${ }^{1}$ School of Science, RMIT University, Bundoora, Victoria, Australia \\ 2 NhaTrang institute of Technology Research and Application, Vietnam Academy of Science and Technology, Nha Trang, Khanh Hoa, Vietnam \\ 3 Institute of Biotechnology, Vietnam Academy of Science and Technology, Cau Giay, Ha Noi, Vietnam \\ 4 Griffith Institute for Drug Discovery, Griffith University, Nathan, Queensland, Australia \\ Corresponding Authors: Dong Van Quyen, Robert J Moore \\ Email address: dvquyen@ibt.ac.vn, rob.moore@rmit.edu.au
}

The widespread occurrence of pathogenic bacteria resistant to last-line antibiotics has resulted in significant challenges in human and veterinary medicine. There is an urgent need for new antimicrobial agents that can be used to control these life threating pathogens. We report the identification of antimicrobial activities, against a broad range of bacterial pathogens, from a collection of marine-derived spore-forming bacteria. Although marine environments have been previously investigated as sources of novel antibiotics, studies on such environments are still limited and there remain opportunities for further discoveries and this study has used resources derived from an under-exploited region, the Vietnam Sea. Antimicrobial activity was assessed against a panel of Gram-positive and Gram-negative bacteria, including several multi-drug resistant pathogens. From a total of 489 isolates, $16.4 \%$ had antimicrobial activity. Of 23 shortlisted isolates with the greatest antimicrobial activity, 22 were Bacillus spp. isolates and one was a Paenibacillus polymyxa isolate. Most of the antimicrobial compounds were sensitive to proteases, indicating that they were proteins rather than secondary metabolites. The study demonstrated that marine bacteria derived from the Vietnam Sea represent a rich resource, producing antimicrobial compounds with activity against a broad range of clinically relevant bacterial pathogens, including important antibiotic resistant pathogens. Several isolates were identified that have particularly broad range activities and produce antimicrobial compounds that may have value for future drug development. 


\section{Broad spectrum antimicrobial activities from spore-} 3 forming bacteria isolated from the Vietnam Sea

6 Chau Minh Khanh ${ }^{1,2}$, Dong Van Quyen ${ }^{3}$, Joshua M. Fraser ${ }^{1}$, Andrew T. Smith ${ }^{4}$, Thi Thu Hao

7 Van ${ }^{1}$, Robert J. Moore ${ }^{1}$

8

$9 \quad{ }^{1}$ School of Science, RMIT University, Bundoora, VIC 3083, Australia

$10{ }^{2}$ NhaTrang institute of Technology Research and Application, Vietnam Academy of Science and 11 Technology, 02 Hung Vuong, Loc Tho, Nha Trang, Khanh Hoa, Vietnam

$12{ }^{3}$ Institute of Biotechnology, Vietnam Academy of Science and Technology, 18 Hoang Quoc Viet, 13 Cau Giay, Ha Noi, Vietnam

$14{ }^{4}$ Griffith Institute for Drug Discovery, Griffith Sciences, Nathan Campus, Griffith University, 15 16

17 Corresponding Authors:

18 Robert J. Moore ${ }^{1}$

19 RMIT University, Bundoora West Campus, Plenty Road, Bundoora, VIC 3083, Australia

20 Email address: rob.moore@rmit.edu.au

21 Dong Van Quyen ${ }^{3}$

22 Institute of Biotechnology, Vietnam Academy of Science and Technology, 18 Hoang Quoc Viet, 23 Cau Giay, Ha Noi, Vietnam

24 Email address: $\underline{\text { dvquyen@ibt.ac.vn }}$

25

26

27

28 
29

30

31

32

33

34

35

36

37

38

39

40

41

42

43

44

45

46

47

48

49

50

51

52

53

54

55

56

57

58

59

60

61

62

63

64

65

66

67

\section{Abstract}

The widespread occurrence of pathogenic bacteria resistant to last-line antibiotics has resulted in significant challenges in human and veterinary medicine. There is an urgent need for new antimicrobial agents that can be used to control these life threating pathogens. We report the identification of antimicrobial activities, against a broad range of bacterial pathogens, from a collection of marine-derived spore-forming bacteria. Although marine environments have been previously investigated as sources of novel antibiotics, studies on such environments are still limited and there remain opportunities for further discoveries and this study has used resources derived from an under-exploited region, the Vietnam Sea. Antimicrobial activity was assessed against a panel of Gram-positive and Gram-negative bacteria, including several multi-drug resistant pathogens. From a total of 489 isolates, $16.4 \%$ had antimicrobial activity. Of 23 shortlisted isolates with the greatest antimicrobial activity, 22 were Bacillus spp. isolates and one was a Paenibacillus polymyxa isolate. Most of the antimicrobial compounds were sensitive to proteases, indicating that they were proteins rather than secondary metabolites. The study demonstrated that marine bacteria derived from the Vietnam Sea represent a rich resource, producing antimicrobial compounds with activity against a broad range of clinically relevant bacterial pathogens, including important antibiotic resistant pathogens. Several isolates were identified that have particularly broad range activities and produce antimicrobial compounds that may have value for future drug development.

\section{Introduction}

The emergence and spread of bacterial pathogens that are resistant to last-line antibiotics, for example carbapenem resistant Gram-negative pathogens, methicillin resistant Staphylococcus aureus (MRSA), and vancomycin resistant Enterococci (VRE), is of great concern in both human and veterinary medicine (Datta \& Huang, 2008; Loomba, Taneja \& Mishra, 2010; Raghunath, 2010; O’Driscoll \& Crank, 2015; Meletis, 2016; Zaman et al., 2017). Antibiotic resistance genes are frequently located on mobile elements such as conjugative plasmids and transposons which facilitate horizontal and vertical transmission, leading to increasing numbers of multi-resistant bacteria worldwide (Devaud, Kayser \& Bächi, 1982; Turner et al., 2014). This high incidence of antibiotic resistant bacteria has serious implications for pathogen control and there is an urgent need for alternatives to the currently available antibiotics to re-control these life-threating antibiotic-resistant pathogens. The discovery of novel antibiotics from terrestrial environments over the last few decades has been challenging, due to an exhaustion of traditional antibiotic sources (Zaman et al., 2017). According to the FDA, approval of new medically important antibiotics had decreased by 56\% over the last few decades (Spellberg et al., 2004) and there has been no evidence for an increase in discovery rate since that study. 
68 The marine environment has been identified as a promising alternative source for antibiotic

69

70

71

72

73

74

75

76

77

78

79

80

81

82

83

84

85

86

87

88

89

90

91

92

93

94

95

96

97

98

99

100

101

102

103

104

105

106 discovery, due to the apparently high abundance of antibiotics produced by various members of diverse marine microbial communities (Mayer et al., 2011; Malve, 2016). It has been hypothesized that marine bacteria are under unusually rigorous selection pressures because of the environmental conditions with which they must contend. They are typically exposed to low levels of nutrition and rapid changes of nutrition and physical conditions due to wave and tidal action. These harsh chemo-physical conditions have selected bacteria that deploy various mechanisms to out-compete other bacteria. Diversification of antimicrobial production is one such adaptation that can be harnessed for occupying and defending an ecological niche (Jensen \& Fenical, 1996; Valentine, 2007; Desriac et al., 2010). It is hypothesized that marine environments may harbor novel antimicrobial producing species, which could be effective against a range of bacteria, including antibiotic resistant pathogenic bacteria. Among the diverse marine bacterial communities, members of the Bacillus genus, characterized as spore formers, have been shown to produce an array of structurally diverse antibiotics, including ribosomally synthesized peptides (bacteriocins), and non-ribosomal secondary metabolites such as polyketide, lipopeptide and bacilysin (Sumi et al., 2014). Bacteriocins are of particular interest. These small cationic peptides commonly have a narrow spectrum of activity, affecting a limited range of bacteria, and a low resistance rate, making them attractive antimicrobials for application against bacteria that have acquired resistance to the current range of available antibiotics (Cotter, Ross \& Hill, 2013; Mathur et al., 2017). Many terrestrially derived bacteriocins have been characterized, but little is known of marine-derived bacteriocins.

Bacteria that produce antimicrobial compounds have the potential to be used directly, for example as probiotics, to combat pathogenic bacteria. Spore-forming bacteria have particular advantages for such applications as the spores are robust and resistant to processing and storage conditions. Hence, spore-forming antimicrobial producing bacteria such as Bacillus and Paenibacillus species can be more easily incorporated into processed food products than more vulnerable species such as Lactobacillus and Lactococcus (Elshaghabee et al., 2017).

Vietnam has more than $3,400 \mathrm{~km}$ of coastline, incorporating a variety of tropical marine ecosystems with abundant marine species and little previous study of bacteria derived from its marine environments. These characteristics make the Vietnam Sea a promising source to explore for novel antimicrobials. The objective of this study was to test the hypothesis that bacteria that produce potentially useful antimicrobials could be found in the Vietnam Sea. A diverse collection of spore-forming bacteria was assembled and evaluated for antimicrobial molecules with activity against a range of important pathogens, including multi-antibiotic resistant pathogens.

\section{Materials \& Methods}

\section{Collection of marine samples and bacterial isolation}


107 Fifty marine samples, from sponges, seaweeds, sediments, and seawaters, were collected by scuba

108

109

110

111

112

113

114

115

116

117

118

119

120

121

122

123

124

125

126

127

128

129

130

131

132

133

134

135

136

137

138

139

140

141

142

143

144

145

146

diving at Nha Trang Bay, around Hon Mieu Island (12.191837, 109.235086), and around Hon Mot Island $(12.173368,109.271591)$ at depth of 5-10 meters, and Hon Rua Island (12.289501, 109.242413) at depth of 1-3 meters. These locations were chosen because of their known high diversity of marine habitats. The collection of environmental samples was approved by the Nha Trang Institute of Technology Research and Application.

Sponge and seaweed samples were washed three times with sterile sea water (SSW) to remove loosely attached external microbes. Ten grams of each sponge and seaweed sample were homogenized with a sterile mortar and pestle in $90 \mathrm{~mL}$ of sterile sea water to release microbes into the seawater. Sediments were air dried and $10 \mathrm{~g}$ vortexed in $90 \mathrm{~mL}$ of sterile seawater to detach microbes. Fifty $\mathrm{mL}$ of sea waters were centrifuged at $2,500 \mathrm{~g}$ for 10 minutes and the $1 \mathrm{~mL}$ at the bottom of the tube was used to resuspend pelleted material. Aliquots of all samples were heated at $80^{\circ} \mathrm{C}$ for 20 minutes to kill non-spore-forming bacteria, followed by serial dilution for plating and isolation. From each dilution $100 \mu \mathrm{L}$ was plated onto laboratory-prepared marine agar (LPMA) (2.5 g/L yeast extract, $5.0 \mathrm{~g} / \mathrm{L}$ peptone, $1.0 \mathrm{~g} / \mathrm{L}$ dextrose, $0.2 \mathrm{~g} / \mathrm{L} \mathrm{K}_{2} \mathrm{HPO}_{4}, 0.05 \mathrm{~g} / \mathrm{L} \mathrm{MgSO}_{4} .7 \mathrm{H}_{2} \mathrm{O}$, $750 \mathrm{~mL} / \mathrm{L}$ aged sea water, $250 \mathrm{~mL} / \mathrm{L}$ tap water, $\mathrm{pH}=7.5$ ). The LPMA was Youshimizu and Kimura medium as modified by Mikhailov et al. (Mikhailov, Romanenko \& Ivanova, 2006). Aged sea water was prepared by storing fresh sea water in the dark for 2-4 weeks to stabilize or neutralize the heavy metals or toxic compounds which may affect bacterial recovery. The inoculated plates were incubated at $30^{\circ} \mathrm{C}$ for up to 4 days. Colonies were re-streaked until only colonies with similar morphologies were observed on the plates. Pure colonies were scrapped off plates to mix in laboratory-prepared marine broth (LPMB) supplemented with $20 \%$ glycerol and stored at $-80^{\circ} \mathrm{C}$.

\section{Primary screening for antimicrobial activity by cross-streak assay}

Each bacterial isolate was streaked vertically onto an LPMA plate and incubated overnight at $30^{\circ} \mathrm{C}$. The six indicator strains used in the initial screening were, S. aureus, B. cereus, C. albicans, E. coli, $P$. aeruginosa, and a methicillin resistant $S$. aureus. Each indicator strain was streaked, horizontally, from the edge of the plate to the pre-grown isolate streak. The cross-streak assay plates were then incubated in the growth conditions appropriate for each indicator strain, as detailed in Table 1. The gap between indicator strain and the test isolates' growth indicated the presence or absence of antimicrobial activity. After inspection of the strength and spectrum of antimicrobial activity, a short-list of isolates with the strongest antimicrobial activity was chosen for more detailed analysis. Their antagonistic activities against 14 pathogens were evaluated.

The cross-streak assay was also used to detect antimicrobial activities produced by the 23 shortlisted isolates against the other members of the group. Each marine isolate was streaked down the middle of LPMA plates, incubated overnight at $30^{\circ} \mathrm{C}$ to allow growth and production of antimicrobial compounds, and then the other 22 isolates were streaked from the edge of the plate to the central streak. The plate was incubated overnight at $37^{\circ} \mathrm{C}$ and antimicrobial activity was determined based on the size of the clear zone between test and indicator bacterial streaks.

Peer] reviewing PDF | (2020:07:51002:1:0:NEW 31 Aug 2020) 
147 Well-diffusion assay

148 Well-diffusion assays were used to determine if antimicrobial activity was secreted into liquid 149 culture supernatant. Muller Hilton agar plates were swabbed with a suspension of indicator 150 bacteria $\left(\mathrm{OD}_{600} \sim 0.08-0.1\right)$. Wells (6mm diameters) were punched from the agar using a sterilized 151 cork cutter and then $50 \mu \mathrm{L}$ of cell free supernatant (CFS) from test cultures grown for 24 hours 152 was added to a well. The CFS in the wells was air dried and plates were incubated at the optimal 153 conditions for growth of the indicator strain (Table 1). The inhibitory effects of antimicrobial 154 within the CFS were observed by appearance of a zone of clearing of the indicator bacteria around 155 the well.

156

157

158

159

160

161

162

163

164

165

166

167

168

169

170

171

172

173

174

175

176

177

178

179

180

181

182

183

184

185

186

187

\section{S rRNA gene amplification, sequencing, and phylogenetic analysis}

Bacteria were sub-cultured into $5 \mathrm{~mL}$ of LB from a single colony. Total genomic DNA (gDNA) was extracted from the overnight culture using a guanidine thiocyanate method, as previously describes (Pitcher, Saunders \& Owen, 1989), and then used as template to amplify the 16S rRNA gene sequences. PCR was conducted using primers with the sequences (5'-3') GGCGTGCCTAATACATGCAA and TACAAGGCCCGGGAACGT. The primers were designed, based on the alignment of the $16 \mathrm{~S}$ rDNA sequences of Bacillus isolates. PCR condition comprised initial denaturation at $98^{\circ} \mathrm{C}$ for 30 seconds, 30 cycles of $98^{\circ} \mathrm{C}$ for 5 seconds, $56^{\circ} \mathrm{C}$ for 10 seconds and $72^{\circ} \mathrm{C}$ for 20 seconds, extension at $72^{\circ} \mathrm{C}$ for 2 minutes; and $4^{\circ} \mathrm{C}$ for 10 minutes. PCR products were checked by electrophoresis in 1\% agarose gel, subsequently purified by QIAquick PCR Purification Kit (Qiagen), and then Sanger-sequenced (Micromon, Monash University, Australia). The 16S rRNA gene sequences are deposited under NCBI GenBank accession numbers MT758446-MT758468. The raw reads were trimmed of unclear nucleotides at both 5' and 3' terminal ends, and subsequently blastn was used to search for homologies in the Bacterial 16S rDNA Database (https://blast.ncbi.nlm.nih.gov/Blast.cgi). The highly homologous 16S rDNA sequences were download for phylogenetic tree construction. All the sequences were aligned using ClustalW (Thompson, Higgins \& Gibson, 1994), and the phylogenetic tree was subsequently constructed in MEGA7 using the neighbor joining method with bootstrap tests performed 1000 times and pairwise detection (Kumar, Stecher \& Tamura, 2016).

\section{Sensitivity of antimicrobial activities to enzyme and heat treatments}

Enzymatic treatments of CFSs were conducted for 3 hours at $37^{\circ} \mathrm{C}$ with pronase-E from Streptomyces griseus; proteinase K; trypsin; and lipase, at final concentrations of $2 \mathrm{mg} / \mathrm{mL}$. All enzymes were purchased from Sigma Aldrich. Heat stability of antimicrobials was determined by incubation of CFSs at $60^{\circ} \mathrm{C}, 80^{\circ} \mathrm{C}$, and $100^{\circ} \mathrm{C}$ for 30 minutes, 60 minutes, and 3 hours. The antimicrobial activities of the treated CFS preparation were evaluated by well-diffusion assay, against Clostridium perfringens.

\section{Growth properties, antibiotic susceptibility testing, and enzyme production of isolates}

The ability of the short-listed isolates to grow on different media was evaluated by spotting $5 \mu \mathrm{L}$ of bacterial cultures onto several different media, including low nutrition media such as marine 
188

189

190

191

192

193

194

195

196

197

198

199

200

201

202

203

204

205

206

207

208

209

210

211

212

213

214

215

216

217

218

219

220

221

222

223

224

225

226

agar (BD Difco 2216) and LPMA, and rich nutritious media such as LB agar and Muller Hilton agar, and incubated at $30^{\circ} \mathrm{C}$ overnight. Aliquots of cultures were spotted on LB agar plates, and incubated under microaerophilic, aerobic, and anaerobic conditions at $30^{\circ} \mathrm{C}$, and aerobically incubated at $40^{\circ} \mathrm{C}$ and $50^{\circ} \mathrm{C}$. To measure $\mathrm{pH}$ tolerance, bacterial cultures were spotted onto LB plates in which the media had been adjusted to $\mathrm{pH}$ 5.0, 6.0, 7.0, 8.0, and 9.0. Sodium chloride tolerance was determined on LB plates supplemented with $0 \%, 1 \%, 2 \%, 4 \%, 6 \%, 8 \%, 10 \%, 12 \%$ and $15 \%(\mathrm{w} / \mathrm{v}) \mathrm{NaCl}$; while bile salt tolerance was carried out on the LB plates supplemented bile salt at final concentration of $0.1 \mathrm{M}, 0.2 \mathrm{M}, 0.3 \mathrm{M}, 0.4 \mathrm{M}, 0.5 \mathrm{M}, 0.6 \mathrm{M}, 0.7 \mathrm{M}$ respectively (Bile Salts Mixture No. 3; Neogen Corporation). For antibiotic susceptibility testing, LB agar plates were prepared supplemented with tetracycline, ampicillin, nalidixic acid, and kanamycin at final concentration of $50 \mu \mathrm{g} / \mathrm{mL}$. The production of proteases and cellulases, amylase was evaluated respectively by spotting of $5 \mu \mathrm{L}$ of bacterial cultures onto skim milk agar; carbon deficient media (CDM) supplemented with 1\% carboxymethylcellulose (CMC), and CDM supplemented with 1\% soluble starch. CDM contained $0.1 \mathrm{~g} / \mathrm{L}$ yeast extract; $0.5 \mathrm{~g} / \mathrm{L}$ peptone; $16.0 \mathrm{~g} / \mathrm{L}$ agar. Plates were incubated at $30^{\circ} \mathrm{C}$ overnight, followed by flushing the CMC plates and starch agar plates with Gram's iodine solution (Sigma Aldrich) for 1 minute. Positive reactions, indicating enzymatic activity, were noted via halo zones around the bacteria spots.

\section{Statistical Analysis}

A two-tailed t-test was used to assess whether there were any statistically significant differences in the rate of isolation of antimicrobial producing isolates from the different marine sources. The statistical analysis was computed in Microsoft Excel with a 5\% level of probability used to indicate significance.

\section{Results}

\section{Antimicrobial activity of thermally resistant, marine spore-forming bacteria}

A total of 389 heat resistant, spore-forming, bacterial isolates were cultured from 50 marine samples (Table 2). They demonstrated a range of colony morphologies (Figure 1). Primary screening against six indicator strains, using the cross-streak assay, identified 64 isolates (16.4\%) with antimicrobial activity (Figure 2A, 2C). The proportion of isolates that exhibited activity against Gram-positive indicator strains, Bacillus cereus (93.7\%), Staphylococcus aureus (84.3\%), Streptococcus faecalis $(87.5 \%)$, was higher than the proportion that exhibited activity against the Gram-negative indicators, Escherichia coli (50\%) and Pseudomonas aeruginosa (4.6\%), and the yeast, Candida albicans (21.4\%). A two-tailed t-test showed that the there was no statistically significant difference in the rate of isolation of antimicrobial producing bacteria from the different types of marine samples. The $\mathrm{p}$ values for the pairwise comparisons amongst all the sample types ranged from 0.37 to 0.77 . 
227 The spectra of antimicrobial activities, exhibited by a select group of the 23 most potent isolates

228

229

230

231

232

233

234

235

236

237

238

239

240

241

242

243

244

245

246

247

248

249

250

251

252

253

254

255

256

257

258

259

260

261

262

263

264

265

266

from the primary screen, were determined against an expanded panel of 14 indicator strains, including important multidrug resistant pathogens. The analyses were performed using two assays: a cross-streak assay and a well-diffusion assay. There was considerable variation in the strength and spectra of antimicrobial activity across the 23 short-listed isolates. The pathogenic indicator strains most commonly affected by the antimicrobial compounds expressed by the screened isolates were the Gram-positive species (Table 3; Figure 3). Of the bacterial indicators, Clostridium perfringens, B. cereus and $S$. aureus were inhibited by $83 \%(19 / 23)$ of the test isolates, whereas the proportion with activity against the Gram-negative indicators; Campylobacter jejuni, $70 \%$ (16/23), Campylobacter coli, 61\% (14/23), was lower. Two antibiotic resistant Gram-positive pathogens; MRSA and VRE were inhibited by respectively 83\% (19/23) and 57\% (13/23) of isolates, while an antibiotic resistant Gram-negative pathogen; multidrug resistant Klebsiella pneumonia (MRKP), was inhibited by only one isolate, P. polymyxa \#23. The Gram-negative bacteria $P$. aeruginos $a$ was also inhibited by $P$. polymyxa \#23. The growth of foodborne pathogens; Listeria monocytogenes, E. coli and Salmonella Enteriditis were depressed by, respectively, 78\%, $44 \%$, and $57 \%$ of the isolates. None of the selected isolates had inhibitory activity against $C$. albicans.

The cross-streak assay was found to be more sensitive than the well-diffusion assay. In most cases antimicrobial activity was detected in both assays but occasionally the activity was less or absent in the well-diffusion assay. This difference was particularly apparent when S. aureus, MRSA and most of Gram-negative pathogens, C. jejuni, C. coli, E. coli and S. Enteriditis, were used as the indicator strains.

\section{Taxonomic analysis of antimicrobial isolates}

Of the 23 of the isolates selected as expressing the most antimicrobial activity, there were 22 Bacillus species isolates and 1 Paenibacillus isolate. Their 16S rRNA gene sequences shared $99 \%$ - 100\% identity with, mostly, terrestrially derived species (Table 4). The phylogenetic tree demonstrated the relationship amongst the marine isolates and to terrestrial isolates (Figure 4). The most commonly identified species amongst the short-listed isolates were $B$. subtilis (10 isolates) and other members of $B$. subtilis group such as B. amyloliquefaciens (5 isolates), B. licheniformis (1 isolate), and B. safensis (1 isolate). In addition, members of other Bacillus groups were also identified including B. pacificus (2 isolates), belonging to B. cereus group; B. halotolerans (3 isolates), and $P$. polymyxa (1 isolate)

\section{Many of the antimicrobials are proteinaceous compounds}

It has previously been shown that protein and non-protein antimicrobial compounds are produced by some terrestrial Bacillus isolates. The proteinaceous nature of some of the antimicrobial activities identified in the marine Bacillus isolate collection was demonstrated by their susceptibility to protease action. For these assays $C$. perfringens was selected as the indicator strain because amongst the indictor strains tested (Table 3) it displayed sensitivity to the highest

Peer) reviewing PDF | (2020:07:51002:1:0:NEW 31 Aug 2020) 
267

268

269

270

271

272

273

274

275

276

277

278

279

280

281

282

283

284

285

286

287

288

289

290

291

292

293

294

295

296

297

298

299

300

301

302

303

304

305

306

percentage of the Bacillus produced antimicrobial compounds. The protease sensitivity of the anti$C$. perfringens activity of the isolates was determined by digesting cell culture supernatants used in the well-diffusion assay with proteases. In 16 of the 19 isolates tested the antimicrobial activities against $C$. perfringens were reduced or lost after treatment with at least one proteolytic enzyme (Table 5). The pronase-E enzyme completely eliminated anti-C. perfringens activity from 10 isolates, while proteinase-K removed the activity from 4 isolates. Some antimicrobials (produced by isolates \#06, \#11, and \#21) were affected by both proteinases and a lipase. Other isolates showed reduced, but not eliminated, antimicrobial activity following protease treatment (\#01, \#08, $\# 20, \# 21)$. The antimicrobial activities produced by isolates \#5,\#18, \#19 were not affected by any of the enzymes used. Heat treatment at $60^{\circ} \mathrm{C}$ for 30 minutes abolished the activity of 12/19 antimicrobials while $7 / 19$ retained activity. Of the isolates in which antimicrobial activity was not affected by proteases, isolates \#05 and \#19 were also resistant to heat treatment whereas anti-C. perfringens activity was abolished when \#18 supernatant was heated.

\section{Antimicrobial activity between the short-listed isolates}

It is hypothesised that bacteria produce antimicrobial compounds to compete within an ecological niche. We therefore investigated whether this group of isolates exhibited any antimicrobial activities against each other. Growth inhibition was detected, using the cross-streak assay, between strains of the same species for isolates B. amyloliquefaciens \#06, \#08, and B. subtilis \#05. Crossspecies antimicrobial activities were detected for many of the isolates, including, $B$. amyloliquefaciens \#06, \#08, \#11,\#13, B. licheniformis \#03; B. safensis \#10; B. halotolerans \#01, and $P$ polymyxa \#23. Particularly, $P$. polymyxa \#23 depressed growth of all the marine Bacillus assayed (Figure 2B, Table 6)

\section{Growth characteristics of antimicrobial-producing isolates}

The basic growth parameters of the 23 isolates were qualitatively evaluated (Table 7). All isolates could grow on various kinds of media. Growth was better in rich nutritious medias such as LuriaBertani (LB), brain heart infusion (BHI), Müller Hinton agar (MH), and blood agar (BA), than growth in less nutritious media such as lab-prepared marine agar (LPMA) and marine broth (MB). All 23 isolates grew vigorously under both aerobic and microaerophilic conditions but not in anaerobic condition, under incubations temperatures of $30^{\circ} \mathrm{C}, 37^{\circ} \mathrm{C}, 40^{\circ} \mathrm{C}, 50^{\circ} \mathrm{C}$, and under $\mathrm{pHs}$ ranging from 6.0 to 9.0. Some isolates had reduced growth at pH5.0. All isolates could grow in media supplemented with $5 \% \mathrm{NaCl}$, and all but isolate $\# 23$ grew in $7 \% \mathrm{NaCl}$. No isolate could tolerate $12 \% \mathrm{NaCl}$. The marine environment, from which the isolates were derived, typically has a salt content of 3.5\%. No isolates grew in LB media supplemented with bile salts, even at lowest concentration tested $(0.1 \mathrm{M})$. All isolates were sensitive to 3 antibiotics; nalidixic acid $(50 \mu \mathrm{g} / \mathrm{mL})$, kanamycin $(50 \mu \mathrm{g} / \mathrm{mL})$ and tetracycline $(50 \mu \mathrm{g} / \mathrm{mL})$, but 14 of the 23 isolates were resistant to ampicillin $(50 \mu \mathrm{g} / \mathrm{mL})$. All the isolates had detectable levels of cellulolytic, proteolytic or amylolytic activity (Figure 2D-F). 


\section{Discussion}

309

310

311

312

313

314

315

316

317

318

319

320

321

322

323

324

325

326

327

328

329

330

331

332

333

334

335

336

337

338

339

340

341

342

343

344

345

346

There is growing interest in the marine environment as a potential source of bacteria that produce novel antimicrobial compounds, particularly bacteriocins. These antimicrobial peptides have been gaining interest as potential drug candidates for clinical treatment of antibiotic resistant pathogens (Cotter, Ross \& Hill, 2013). In this study, spore-forming bacteria isolated from the coastal marine environment of Nha Trang (Vietnam Sea) were screened to identify Bacillus isolates that produce antimicrobial compounds. Members of the Bacillus genus were targeted because they are wellrecognized as producers of structurally diverse bacteriocins. Of the various types of marine samples collected, the antimicrobial producing isolates were most frequently recovered from sponges, followed by sediments, seaweeds, and sea-water samples. Marine sponges have multiporous structures that may trap and maintain high bacterial densities, leading to higher recovery rates of antimicrobial producers. The recovery rate in marine sponges, at $7.6 \%$, was at the lower end of the range reported in previous studies (5.5\% to 50.0\%) (Laport \& Muricy, 2008). A lower recovery rate of antimicrobial producing isolates was also seen from seaweeds, at $3.6 \%$, whereas previous studies had identified them from seaweeds at $11.0 \%-16.0 \%$ (Lemos, Toranzo \& Barja, 1985; Penesyan et al., 2009). The differences between this study and previous studies could be due to geographical differences, marine conditions, or heat treatment to select the spore-formers that may eliminate the metabolically active vegetative cells.

The methods used to detect antimicrobial activity had different levels of sensitivity. The welldiffusion assay was less sensitive than the cross-streak assay. This effect was most obvious with the failure to detect activity against Gram-negative bacteria, S. aureus and MRSA, when the latter assay was used. This may occur because of the production of multiple antimicrobial compounds, with variable relative expression levels in liquid and solid media-based cultivation. Many studies have reported the influence of various factors on bacteriocin production in liquid culture such as, type of culture media; $\mathrm{pH}$, temperature, growth phase, and quorum sensing regulation (GutowskiEckel et al., 1994; Shanker \& Federle, 2017; Yang et al., 2018).

The most commonly identified species amongst the 23 shortlisted marine isolates that exhibited the strongest antimicrobial activities, were members of the Bacillus subtilis group. These species have been widely reported in both marine environments and terrestrial environments and are able to tolerate the broad environmental conditions (nutrients, pHs, chemo-physical conditions) that are typically found in marine environments. For example, a study by Ivanova et al., reported that $55.0 \%(11 / 20)$ of endospore-forming bacteria isolated from different areas of the Pacific Ocean were B. subtilis species (Ivanova et al., 1999). B. subtilis, B. amyloliquefaciens, B. pumilus and $P$. polymyxa were all identified amongst aerobic spore-forming isolates from marine sources from the Gulf of Mexico, or isolated from seaweed samples collected from the Irish Sea (Siefert et al., 2000; Luz Prieto et al., 2012). Other typical marine species, for example, B. aquimaris, B. algicola and $B$. hwajinpoensis may require additional special nutrients or salts to recover or could have been eliminated during screening and shortlisting based on the strength of antimicrobial activity.

Peer) reviewing PDF | (2020:07:51002:1:0:NEW 31 Aug 2020) 
347 The marine Bacillus/Paenibacillus isolates that we have characterized had broad antimicrobial 348 activity against a range of human, veterinary and food borne pathogens, including three antibiotic 349 resistant pathogens (MRKP, MRSA and VRE). B. amyloliquefaciens \#06, \#08, \#11, \#13, B. 350 halotolerans \#01, \#19, B. licheniformis \#03, B. safensis \#10, P. polymyxa \#23 had broad

351

352

353

354

355

356

357

358

359

360

361

362

363

364

365

366

367

368

369

370

371

372

373

374

375

376

377

378

379

380

381

382

383

384

385

386 antimicrobial activity against both Gram-positive and Gram-negative pathogen indicator strains and against other marine Bacillus of different species. This indicated production of either multiple antimicrobial compounds by a single Bacillus, or a broad-spectrum antimicrobial compound. Members of the Bacillus genus are known to produce various types of antimicrobial compounds including polyketides, lipopeptides, bacteriocins, bacilysin, and volatile compounds (Mondol, Shin \& Islam, 2013). The synergistic effects of these antimicrobials could result in a broad spectrum of antimicrobial activity, such as noted for a number of the isolates in this study. Also, production of broad-spectrum bacteriocin was recently reported for a marine Bacillus; sonorensin, identified from a marine $B$. sonorensis isolate, exhibited broad-spectrum antibacterial activity towards both Gram-positive and Gram-negative bacteria (Chopra et al., 2014). Amongst Grampositive bacteria, such as Bacillus spp., the expression of bacteriocins and other antimicrobial compounds with activity against other Gram-positive bacteria is widespread and extensively studied. However, the production of compounds with activity against Gram-negative bacteria is less common, therefore, the isolates that have antimicrobial activity against Gram-negative bacteria are of particular interest. Rarely observed antimicrobial activities such as that observed against Campylobacter, P. aeruginosa, and even multidrug-resistant $K$. pneumonia, represent potentially novel compounds that, in future work, should be purified and structurally characterized. The $P$. polymyxa \#23 isolate had the strongest and broadest activity and it is likely that the activity against Gram-negative bacteria results from the expression of polymyxin, which has long been known to have such activity (Stansly \& Schlosser, 1947; Poirel, Jayol \& Nordmann, 2017). The other isolates with activity against some of the Gram-negative bacteria tested, for example $B$. amyloliquefaciens \#11, which had significant activity against both Campylobacter species but lesser activity against E. coli and Salmonella, appears to indicate a spectrum of activity that has not previously been reported and so the compound responsible may be novel and hence warrants further investigation.

The finding that many of the compounds that had activity against $C$. perfringens were inactivated by proteases, indicated that the antimicrobial compounds produced probably included bacteriocins. Interestingly, the production of large quantities of these antimicrobial compounds for drug development in the future could likely be achieved as it was demonstrated that most of the isolates were well adapted to a broad range of growth conditions (variations in nutrients, $\mathrm{pH}$, salt concentration, and temperature). These characteristics of the isolates represent advantages that could facilitate manufacturing processes, product storage, and the potential harnessing of these isolates for in vivo use in animal or food applications.

These marine derived Bacillus/Paenibacillus isolates were also shown to have proteolytic, cellulolytic and amylolytic activity and hence may represent a promising source of important industrial enzymes such as proteases, cellulases, and amylases. Marine derived enzymes have 
387 been noted to have significant advantages in manufacturing because they commonly have high 388 adaptability to high-salt concentration, and fluctuating temperature, $\mathrm{pH}$, organic solvents, and ions 389 (Debashish et al., 2005)

390 In conclusion, the bacteria in this collection of marine Bacillus isolates express a range of 391 antimicrobial activities, some of which may represent novel compounds that warrant further study.

392

393

394

395

396

397

398

399

400

401

402

403

404

405

406

407

408

409

410

411

412

413

414

415

416

417

418

\section{Conclusions}

It was hypothesized that the marine environment, particularly understudied regions abundant in varied marine habitats, such as the Vietnam Sea, would provide a rich source of bacteria that produce antimicrobial compounds. A survey of heat-resistant spore-forming bacteria found that $16.4 \%$ of isolates produced detectable levels of antimicrobial activity. Bacterial isolates were identified that had broad spectra of activity against both Gram-positive and Gram-negative pathogenic bacteria. Further analysis of a select group of isolates with the broadest activity profile showed that most of the antimicrobial compounds were sensitive to proteases, indicating that they were proteins rather than secondary metabolites. The study demonstrated that marine bacteria derived from the Vietnam Sea represent an interesting resource, producing antimicrobial compounds with activity against a range of clinically relevant bacterial pathogens, including important antibiotic resistant pathogens. Further biochemical characterization now needs to be undertaken to characterize the antimicrobial compounds, especially to define those that are novel.

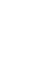

\section{References}

Chopra L, Singh G, Choudhary V, Sahoo DK. 2014. Sonorensin: an antimicrobial peptide, belonging to the heterocycloanthracin subfamily of bacteriocins, from a new marine isolate, Bacillus sonorensis MT93. Applied and Environmental Microbiology 80:29812990. DOI: 10.1128/AEM.04259-13.

Cotter PD, Ross RP, Hill C. 2013. Bacteriocins - a viable alternative to antibiotics? Nature Reviews. Microbiology 11:95-105. DOI: 10.1038/nrmicro2937. 
419 Datta R, Huang SS. 2008. Risk of infection and death due to methicillin-resistant Staphylococcus 420 aureus in long-term carriers. Clinical Infectious Diseases 47:176-181. DOI:

421 $10.1086 / 589241$

422

423

424

425

426

427

428

429

430

431

432

433

434

435

436

437

438

439

440

441

Debashish G, Malay S, Barindra S, Joydeep M. 2005. Marine enzymes. Advances in Biochemical Engineering/Biotechnology 96:189-218. DOI: 10.1007/b135785.

Desriac F, Defer D, Bourgougnon N, Brillet B, Le Chevalier P, Fleury Y. 2010. Bacteriocin as weapons in the marine animal-associated bacteria warfare: Inventory and potential applications as an aquaculture probiotic. Marine Drugs 8:1153-1177. DOI: $10.3390 / \mathrm{md} 8041153$.

Devaud M, Kayser FH, Bächi B. 1982. Transposon-mediated multiple antibiotic resistance in Acinetobacter strains. Antimicrobial Agents and Chemotherapy 22:323-329.

Elshaghabee FMF, Rokana N, Gulhane RD, Sharma C, Panwar H. 2017. Bacillus as potential probiotics: Status, concerns, and future perspectives. Frontiers in Microbiology 8:1490. DOI: $10.3389 /$ fmicb.2017.01490.

Gutowski-Eckel Z, Klein C, Siegers K, Bohm K, Hammelmann M, Entian KD. 1994. Growth phase-dependent regulation and membrane localization of $\mathrm{SpaB}$, a protein involved in biosynthesis of the lantibiotic subtilin. Applied and Environmental Microbiology 60:111.

Ivanova EP, Vysotskii MV, Svetashev VI, Nedashkovskaya OI, Gorshkova NM, Mikhailov VV, Yumoto N, Shigeri Y, Taguchi T, Yoshikawa S. 1999. Characterization of Bacillus strains of marine origin. International Microbiology 2:267-271.

Jensen PR, Fenical W. 1996. Marine bacterial diversity as a resource for novel microbial products. Journal of Industrial Microbiology 17:346-351. DOI: 10.1007/BF01574765. 
442 Kumar S, Stecher G, Tamura K. 2016. MEGA7: Molecular evolutionary genetics analysis

443 version 7.0 for bigger datasets. Molecular Biology and Evolution 33:1870-1874. DOI:

$444 \quad 10.1093 / \mathrm{molbev} / \mathrm{msw} 054$.

445 Laport MS, Muricy OCSS and G. 2008. Marine sponges: Potential sources of new antimicrobial 446 drugs. Current Pharmaceutical Biotechnology 10:86-105. DOI:

$447 \quad 10.2174 / 138920109787048625$.

448 Lemos ML, Toranzo AE, Barja JL. 1985. Antibiotic activity of epiphytic bacteria isolated from 449 intertidal seaweeds. Microbial Ecology 11:149-163. DOI: 10.1007/BF02010487.

450 Loomba PS, Taneja J, Mishra B. 2010. Methicillin and vancomycin resistant S. aureus in 451 hospitalized patients. Journal of Global Infectious Diseases 2:275-283. DOI: 10.4103/0974-777X.68535.

453

454

455

456

457

458

459

460

461

462

463

464

Luz Prieto M, O’Sullivan L, Tan SP, McLoughlin P, Hughes H, O’Connor PM, Cotter PD, Lawlor PG, Gardiner GE. 2012. Assessment of the bacteriocinogenic potential of marine bacteria reveals lichenicidin production by seaweed-derived Bacillus spp. Marine Drugs 10:2280-2299. DOI: $10.3390 / \mathrm{md} 10102280$.

Malve H. 2016. Exploring the ocean for new drug developments: Marine pharmacology. Journal of Pharmacy \& Bioallied Sciences 8:83-91. DOI: 10.4103/0975-7406.171700.

Mathur H, Field D, Rea MC, Cotter PD, Hill C, Ross RP. 2017. Bacteriocin-antimicrobial synergy: A medical and food perspective. Frontiers in Microbiology 8:1205. DOI: 10.3389/fmicb.2017.01205.

Mayer AMS, Rodríguez AD, Berlinck RGS, Fusetani N. 2011. Marine pharmacology in 2007-8: Marine compounds with antibacterial, anticoagulant, antifungal, anti-inflammatory, antimalarial, antiprotozoal, antituberculosis, and antiviral activities; affecting the immune 
465

466

467

468

469

470

471

472

473

474

475

476

477

478

479

480

481

482

483

484

485

486

and nervous system, and other miscellaneous mechanisms of action. Comparative Biochemistry and Physiology Part C: Toxicology \& Pharmacology 153:191-222. DOI: 10.1016/j.cbpc.2010.08.008.

Meletis G. 2016. Carbapenem resistance: overview of the problem and future perspectives. Therapeutic Advances in Infectious Disease 3:15-21. DOI: 10.1177/2049936115621709.

Mikhailov VV, Romanenko LA, Ivanova EP. 2006. The genus Alteromonas and related proteobacteria. In: Dworkin M, Falkow S, Rosenberg E, Schleifer K-H, Stackebrandt E eds. The Prokaryotes: Volume 6: Proteobacteria: Gamma Subclass. New York, NY: Springer, 597-645. DOI: 10.1007/0-387-30746-X_20.

Mondol MAM, Shin HJ, Islam MT. 2013. Diversity of secondary metabolites from marine Bacillus species: Chemistry and biological activity. Marine Drugs 11:2846-2872. DOI: $10.3390 / \mathrm{md} 11082846$.

O’Driscoll T, Crank CW. 2015. Vancomycin-resistant enterococcal infections: epidemiology, clinical manifestations, and optimal management. Infection and Drug Resistance 8:217230. DOI: $10.2147 /$ IDR.S54125.

Penesyan A, Marshall-Jones Z, Holmstrom C, Kjelleberg S, Egan S. 2009. Antimicrobial activity observed among cultured marine epiphytic bacteria reflects their potential as a source of new drugs. FEMS Microbiology Ecology 69:113-124. DOI: 10.1111/j.15746941.2009.00688.x.

Pitcher DG, Saunders NA, Owen RJ. 1989. Rapid extraction of bacterial genomic DNA with guanidium thiocyanate. Letters in Applied Microbiology 8:151-156. DOI: 10.1111/j.1472-765X.1989.tb00262.x. 
487 Poirel L, Jayol A, Nordmann P. 2017. Polymyxins: Antibacterial activity, susceptibility testing, 488 and resistance mechanisms encoded by plasmids or chromosomes. Clinical Microbiology 489 Reviews 30:557-596. DOI: 10.1128/CMR.00064-16.

490 Raghunath D. 2010. New metallo $\beta$-lactamase NDM-1. The Indian Journal of Medical Research 491 $132: 478-481$.

492 493 494 495 496 497 498 499 500 501 502 503 504 505 506 507 508 509 Streptococcus pneumoniae and mutans. Genes 8:15. DOI: 10.3390/genes8010015.

Siefert JL, Larios-Sanz M, Nakamura LK, Slepecky RA, Paul JH, Moore ERB, Fox GE, Jurtshuk Jr Peter. 2000. Phylogeny of marine Bacillus Isolates from the Gulf of Mexico. Current Microbiology 41:84-88. DOI: 10.1007/s002840010098.

Spellberg B, Powers JH, Brass EP, Miller LG, Edwards JE. 2004. Trends in antimicrobial drug development: Implications for the future. Clinical Infectious Diseases 38:1279-1286. DOI: $10.1086 / 420937$.

Stansly PG, Schlosser ME. 1947. Studies on polymyxin: Isolation and identification of Bacillus polymyxa and differentiation of polymyxin from certain known antibiotics. Journal of Bacteriology 54:549-556.

Sumi CD, Yang BW, Yeo I-C, Hahm YT. 2014. Antimicrobial peptides of the genus Bacillus: a new era for antibiotics. Canadian Journal of Microbiology 61:93-103. DOI: 10.1139/cjm-2014-0613.

Thompson JD, Higgins DG, Gibson TJ. 1994. CLUSTAL W: improving the sensitivity of progressive multiple sequence alignment through sequence weighting, position-specific gap penalties and weight matrix choice. Nucleic Acids Research 22:4673-4680. DOI: $10.1093 / \mathrm{nar} / 22.22 .4673$. 
510 Turner PE, Williams ESCP, Okeke C, Cooper VS, Duffy S, Wertz JE. 2014. Antibiotic

511 resistance correlates with transmission in plasmid evolution. Evolution 68:3368-3380.

$512 \quad$ DOI: $10.1111 /$ evo.12537.

513 Valentine DL. 2007. Adaptations to energy stress dictate the ecology and evolution of the

514 Archaea. Nature Reviews Microbiology 5:316-323. DOI: 10.1038/nrmicro1619.

515 Yang E, Fan L, Yan J, Jiang Y, Doucette C, Fillmore S, Walker B. 2018. Influence of culture

516 media, $\mathrm{pH}$ and temperature on growth and bacteriocin production of bacteriocinogenic

517 lactic acid bacteria. AMB Express 8:10. DOI: 10.1186/s13568-018-0536-0.

518 Zaman SB, Hussain MA, Nye R, Mehta V, Mamun KT, Hossain N. 2017. A review on antibiotic

519 resistance: Alarm bells are ringing. Cureus 9:e1403. DOI: 10.7759/cureus.1403.

520

521 


\section{Figure Legends}

523

524

525

526

527

528

529

530

531

532

533

534

535

536

537

538

539

540

541

542

543

544

545

546

547

548
Figure 1. Morphological diversity of the marine isolates. Colony morphologies of some pure marine spore- forming bacteria. The symbol \# indicated the isolate number amongst the 23 shortlisted isolates. ' $\mathrm{C}$ ' is an example of a primary culture plate, in this case from a seaweed sample, from which isolates were subsequently colony purified. Photo credit: Chau Minh Khanh.

Figure 2. Bioactivity assays. Antimicrobials activity screened by (A, B) cross-streak assay and (C) well-diffusion assay. (A) The cross-streak assay to identify antimicrobial producing bacteria against 6 indicators including; (1) S. faecalis; (2) B. cereus; (3) P. aeruginosa; (4) E. coli; (5) S. aureus; (6) C. albicans. (B) The illustration of cross-activity exhibited by P. polymyxa \#23 (as a representative) against growth of other marine species. Notably, $P$. polymyxa killed all other marine Bacillus excepting itself \#23 (as negative control). (C) The growth of MRSA as indictor was depressed by two isolates' culture supernatants. (D) Proteolytic activity screened on skim milk agar. (E) Cellulose degradation activity screened on CMC agar. (E) Amylase production screened on starch agar. Photo credit: Chau Minh Khanh.

Figure 3. Antimicrobial activities amongst the short-listed 23 isolates against 14 pathogenic indicator strains. Chart was constructed based on the value obtained from Table 5. WD: Welldiffusion assay, CS: Cross-streak assay.

Figure 4. Phylogenetic tree of the short-listed 23 antimicrobial producing isolates. The neighbor-joining phylogenetic tree was constructed using the maximum composite likelihood method, bootstrap method of 1000 replication and pairwise deletion by MEGA 7. In this tree, 23 marine isolates were displayed by number value, while all reference strains bacteria were closely related bacteria identified and downloaded from NCBI. 


\section{Table $\mathbf{1}$ (on next page)}

List of indicators strains used for antimicrobial screening experiments

Standard media were MRS, De Man, Rogosa and Sharpeagar; MH, Muller Hilton agar; BA, Muller Hilton agar supplemented with 5\% sheep blood. Microaerophilic and anaerobic condition were obtained with Gas-Pak 
1 Table 1. List of indicators strains used for antimicrobial screening experiments

\begin{tabular}{|c|c|c|c|}
\hline No & Strain & Origin/ Strain storage & Media/ growth condition \\
\hline & Gram- positive bacteria & & \\
\hline 1 & Streptococcus faecalis & ATCC 29212 & $\mathrm{MH} / 37^{\circ} \mathrm{C} /$ aerobic \\
\hline 2 & Lactobacillus plantarum & RMIT university & $\mathrm{MRS} / 37^{\circ} \mathrm{C} /$ aerobic \\
\hline 3 & Bacillus cereus & ATCC 10876 & $\mathrm{MH} / 30^{\circ} \mathrm{C} /$ aerobic \\
\hline 4 & Staphylococcus aureus & ATCC 25923 & $\mathrm{MH} / 37^{\circ} \mathrm{C} /$ aerobic \\
\hline 5 & Listeria monocytogenes & Human pathogen, RMIT & $\mathrm{BA} / 37^{\circ} \mathrm{C} /$ aerobic \\
\hline \multirow[t]{2}{*}{6} & Clostridium perfringens & Chicken pathogen, RMIT & $\mathrm{MH} / 37^{\circ} \mathrm{C} /$ anaerobic \\
\hline & Gram- negative bacteria & & \\
\hline 7 & Salmonella Enteritidis & ATCC 13076 & $\mathrm{MH} / 37^{\circ} \mathrm{C} /$ aerobic \\
\hline 8 & Escherichia coli & ATCC 25922 & $\mathrm{MH} / 37^{\circ} \mathrm{C} /$ aerobic \\
\hline 9 & Pseudomonas aeruginosa & ATCC 15442 & $\mathrm{MH} / 37^{\circ} \mathrm{C} /$ aerobic \\
\hline 10 & Campylobacter jejuni & Chicken pathogen, RMIT & $\mathrm{BA} / 37^{\circ} \mathrm{C} /$ microaerophilic \\
\hline \multirow[t]{2}{*}{11} & Campylobacter coli & Chicken pathogen, RMIT & $\mathrm{BA} / 37^{\circ} \mathrm{C} /$ microaerophilic \\
\hline & Yeast & & \\
\hline \multirow[t]{2}{*}{12} & Candida albicans & ATCC 10231 & $\mathrm{MH} / 30^{\circ} \mathrm{C} /$ aerobic \\
\hline & Antibiotic resistant pathogens & & \\
\hline \multirow[t]{2}{*}{13} & Methicillin resistant & Human pathogen, RMIT & $\mathrm{MH} / 37^{\circ} \mathrm{C} /$ aerobic \\
\hline & Staphylococcus aureus (MRSA) & & \\
\hline \multirow[t]{2}{*}{14} & Vancomycin resistant & Human pathogen, RMIT & $\mathrm{MRS} / 37^{\circ} \mathrm{C} /$ aerobic \\
\hline & Enterococcus faecalis (VRE) & & \\
\hline 15 & $\begin{array}{l}\text { Multidrug resistant Klebsiella } \\
\text { pneumonia (MRKP) }\end{array}$ & Human pathogen, RMIT & $\mathrm{MH} / 37^{\circ} \mathrm{C} /$ aerobic \\
\hline
\end{tabular}

2 Standard media were MRS, De Man, Rogosa and Sharpe agar; MH, Muller Hilton agar; BA, Muller Hilton

3 agar supplemented with 5\% sheep blood. Microaerophilic and anaerobic condition were obtained with Gas-

$4 \quad$ Pak 
Table 2 (on next page)

Antimicrobial producing bacteria identified from marine samples 
1 Table 2. Antimicrobial producing bacteria identified from marine samples

\begin{tabular}{lllll}
\hline & $\begin{array}{l}\text { Number of marine } \\
\text { samples collected }\end{array}$ & $\begin{array}{l}\text { Number of isolated } \\
\text { spore-forming bacteria }\end{array}$ & $\begin{array}{l}\text { Number of } \\
\text { antimicrobial isolates }\end{array}$ & $\begin{array}{l}\text { Percentage of isolates } \\
\text { with antimicrobial } \\
\text { activity }\end{array}$ \\
\hline Sponges & 16 & 183 & 28 & $14.8 \%$ \\
Seaweeds & 13 & 92 & 15 & $16.3 \%$ \\
Sediments & 13 & 81 & 16 & $19.8 \%$ \\
Sea water & 8 & 33 & 6 & $18.2 \%$ \\
Total & 50 & 389 & 64 & $16.5 \%$ \\
\hline
\end{tabular}




\section{Table 3 (on next page)}

Antimicrobial activity of short-listed isolates against 14 indicators strains.

The antimicrobial activities were evaluated by well diffusion assay (WD) and cross streak assay (CS).

+ : zone of inhibition observed with clear halo of growth inhibition in at least one time point; ++ and +++ : increased activity as assessed visually by the increased diameter of the inhibition zone; -: no inhibition. The percentage values were calculated based on the ratio between number of isolates with antimicrobial activity against the indicator strain and the total 23 isolates tested. 
1 Table 3. Antimicrobial activity of short-listed isolates against 14 indicators strains. The antimicrobial activities were evaluated by

2 well diffusion assay (WD) and cross streak assay (CS).

\begin{tabular}{|c|c|c|c|c|c|c|c|c|c|c|c|c|c|c|c|c|c|c|c|c|c|c|c|c|}
\hline & \multicolumn{2}{|c|}{$\# 01$} & \multicolumn{2}{|c|}{$\# 02$} & \multicolumn{2}{|c|}{$\# 03$} & \multicolumn{2}{|c|}{$\# 04$} & \multicolumn{2}{|c|}{$\# 05$} & \multicolumn{2}{|c|}{$\# 06$} & \multicolumn{2}{|c|}{$\# 07$} & \multicolumn{2}{|c|}{$\# 08$} & \multicolumn{2}{|c|}{$\# 09$} & \multicolumn{2}{|c|}{$\# 10$} & \multicolumn{2}{|c|}{$\# 11$} & \multicolumn{2}{|c|}{$\# 12$} \\
\hline & $\mathrm{CS}$ & WD & $\mathrm{CS}$ & WD & $\mathrm{CS}$ & WD & $\mathrm{CS}$ & WD & $\mathrm{CS}$ & WD & $\mathrm{CS}$ & WD & $\mathrm{CS}$ & WD & $\mathrm{CS}$ & WD & $\mathrm{CS}$ & WD & $\mathrm{CS}$ & WD & $\mathrm{CS}$ & WD & $\mathrm{CS}$ & WD \\
\hline Clostridium perfringens & ++ & +++ & ++ & + & - & - & + & + & ++ & +++ & ++ & ++ & - & - & +++ & ++ & - & - & + & + & +++ & ++ & ++ & + \\
\hline Staphylococcus aureus & +++ & ++ & ++ & - & + & - & - & - & + & + & +++ & - & - & - & +++ & - & - & - & ++ & ++ & ++ & - & ++ & - \\
\hline Bacillus cereus & ++ & ++ & ++ & ++ & - & - & + & - & + & ++ & +++ & ++ & - & - & +++ & +++ & ++ & - & + & + & +++ & ++ & + & + \\
\hline Listeria monocytogenes & ++ & ++ & ++ & + & - & - & + & - & - & - & +++ & ++ & + & - & ++ & + & - & - & - & - & ++ & + & - & - \\
\hline Lactobacillus plantarum & ++ & + & + & + & + & + & - & - & - & - & ++ & ++ & - & - & ++ & ++ & - & - & + & + & ++ & ++ & - & - \\
\hline Candida albicans & - & - & - & - & - & - & - & - & - & - & - & - & - & - & - & - & - & - & - & - & - & - & - & - \\
\hline Escherichia coli & + & - & + & - & - & - & - & - & + & - & - & - & - & - & + & + & - & - & - & - & + & + & + & - \\
\hline Salmonella Enteritidis & + & - & - & - & - & - & & - & - & - & ++ & - & + & - & ++ & + & - & - & - & - & ++ & + & + & - \\
\hline Campylobacter jejuni & ++ & + & ++ & + & - & - & - & - & ++ & - & ++ & ++ & + & - & ++ & ++ & - & - & - & - & +++ & ++ & - & - \\
\hline Pseudomonas aeruginosa & - & - & - & - & - & - & - & - & + & - & - & - & - & - & - & - & - & - & - & - & - & - & - & - \\
\hline MRSA & +++ & ++ & ++ & - & + & - & - & - & + & + & +++ & - & - & - & +++ & - & - & - & ++ & ++ & ++ & - & ++ & - \\
\hline VRE & ++ & ++ & ++ & ++ & - & - & + & + & - & - & + & - & - & - & +++ & +++ & - & - & ++ & ++ & ++ & ++ & + & ++ \\
\hline MRKP & - & & - & & - & - & - & - & - & - & - & - & - & - & - & - & - & - & - & - & - & - & - & - \\
\hline
\end{tabular}




\begin{tabular}{|c|c|c|c|c|c|c|c|c|c|c|c|c|c|c|c|c|c|c|c|c|c|c|c|c|}
\hline & \multicolumn{2}{|c|}{$\# 13$} & \multicolumn{2}{|c|}{$\# 14$} & \multicolumn{2}{|c|}{$\# 15$} & \multicolumn{2}{|c|}{$\# 16$} & \multicolumn{2}{|c|}{ \#17 } & \multicolumn{2}{|c|}{$\# 18$} & \multicolumn{2}{|c|}{$\# 19$} & \multicolumn{2}{|c|}{$\# \mathbf{2 0}$} & \multicolumn{2}{|c|}{$\# 21$} & \multicolumn{2}{|c|}{$\# 22$} & \multicolumn{2}{|c|}{$\# 23$} & \multicolumn{2}{|c|}{ Percent (\%) } \\
\hline & $\mathrm{CS}$ & WD & $\mathrm{CS}$ & WD & $\mathrm{CS}$ & WD & $\mathrm{CS}$ & WD & $\mathrm{CS}$ & WD & $\mathrm{CS}$ & WD & $\mathrm{CS}$ & WD & $\mathrm{CS}$ & WD & $\mathrm{CS}$ & WD & $\mathrm{CS}$ & WD & $\mathrm{CS}$ & WD & $\mathrm{CS}$ & WD \\
\hline Clostridium perfringens & +++ & +++ & ++ & + & ++ & + & ++ & + & ++ & ++ & ++ & + & ++ & ++ & ++ & + & +++ & +++ & ++ & - & ++ & + & 86.7 & 82.6 \\
\hline Staphylococcus aureus & +++ & - & +++ & - & +++ & - & +++ & - & ++ & - & ++ & - & ++ & +++ & +++ & - & - & - & +++ & - & +++ & + & 82.6 & 21.7 \\
\hline Bacillus cereus & ++ & +++ & +++ & ++ & +++ & ++ & +++ & ++ & ++ & ++ & ++ & ++ & ++ & ++ & ++ & ++ & ++ & ++ & ++ & ++ & ++ & ++ & 82.6 & 82.6 \\
\hline Listeria monocytogenes & ++ & ++ & +++ & +++ & +++ & ++ & +++ & ++ & ++ & ++ & ++ & +++ & ++ & - & +++ & +++ & ++ & ++ & ++ & ++ & ++ & - & 78.2 & 60.8 \\
\hline Lactobacillus plantarum & ++ & +++ & - & - & - & - & - & - & - & - & - & - & ++ & ++ & - & - & ++ & ++ & - & - & + & + & 47.8 & 47.8 \\
\hline Candida albicans & - & - & - & - & - & - & - & - & - & - & - & - & - & - & - & - & - & - & - & - & - & - & 0 & 0 \\
\hline Escherichia coli & ++ & + & - & - & - & - & - & - & - & - & - & - & ++ & - & ++ & - & - & - & - & - & ++ & ++ & 43.5 & 17.3 \\
\hline Salmonella Enteritidis & ++ & - & - & - & + & - & + & - & + & - & + & - & ++ & - & ++ & - & +++ & + & + & - & +++ & ++ & 56.5 & 17.3 \\
\hline Campylobacter jejuni & + & - & ++ & - & + & - & + & - & ++ & - & ++ & - & - & - & - & - & + & - & ++ & - & ++ & ++ & 69.5 & 26 \\
\hline Pseudomonas aeruginosa & - & - & - & - & - & - & - & - & - & - & - & - & - & - & - & - & - & - & - & - & ++ & ++ & 4.3 & 4.3 \\
\hline MRSA & +++ & - & +++ & ++ & +++ & ++ & +++ & ++ & ++ & ++ & ++ & +++ & ++ & + & +++ & ++ & - & - & +++ & ++ & +++ & ++ & 82.6 & 21.7 \\
\hline$V R E$ & ++ & +++ & - & - & - & - & - & - & - & - & + & + & + & ++ & - & - & ++ & ++ & - & - & + & + & 56.5 & 52.2 \\
\hline$M R K P$ & - & - & - & - & - & - & - & - & - & - & - & - & - & - & - & - & - & - & - & - & ++ & ++ & 4.3 & 4.3 \\
\hline
\end{tabular}

7 +: zone of inhibition observed with clear halo of growth inhibition in at least one time point; ++ and +++: increased activity as assessed

8 visually by the increased diameter of the inhibition zone; -: no inhibition. The percentage values were calculated based on the ratio

9 between number of isolates with antimicrobial activity against the indicator strain and the total 23 isolates tested. 


\section{Table 4 (on next page)}

Closest species, by 16S rRNA gene similarity, of antimicrobial producing isolates

Identified by BLASTn of 16S rDNA sequence against the NCBI 16S rDNA database.

*NCBI GenBank accession number 
1 Table 4. Closest species, by 16S rRNA gene similarity, of antimicrobial producing isolates. Identified

2 by BLASTn of 16S rDNA sequence against the NCBI 16S rDNA database.

\begin{tabular}{llll}
\hline Isolate & Accession* & Closest species & Identity (\%) \\
\hline$\# 01$ & MT758446 & B. halotolerans / B. mojavensis / B. subtilis subsp. spizizenii & 100 \\
$\# 02$ & MT758447 & B. subtilis / B. tequilensis & 100 \\
$\# 03$ & MT758448 & B. licheniformis / B. haynesii & 99.92 \\
$\# 04$ & MT758449 & B. subtilis / B. tequilensis & 100 \\
$\# 05$ & MT758450 & B. subtilis / B. tequilensis & 100 \\
$\# 06$ & MT758451 & B. amyloliquefaciens & 99.92 \\
$\# 07$ & MT758452 & B. pacificus / B. paranthracis / B. cereus & 100 \\
$\# 08$ & MT758453 & B. amyloliquefaciens & 99.92 \\
$\# 09$ & MT758454 & B. pacificus / B. paranthracis / B. cereus & 100 \\
$\# 10$ & MT758455 & B. safensis / B. australimaris / B. pumilus & 100 \\
$\# 11$ & MT758456 & B. amyloliquefaciens & 99.92 \\
$\# 12$ & MT758457 & B. subtilis / B. tequilensis & 100 \\
$\# 13$ & MT758458 & B. amyloliquefaciens & 99.92 \\
$\# 14$ & MT758459 & B. subtilis / B. tequilensis & 100 \\
$\# 15$ & MT758460 & B. amyloliquefaciens & 99.92 \\
$\# 16$ & MT758461 & B. subtilis / B. tequilensis & 99.87 \\
$\# 17$ & MT758462 & B. subtilis / B. tequilensis & 99.92 \\
$\# 18$ & MT758463 & B. subtilis / B. tequilensis & 99.76 \\
$\# 19$ & MT758464 & B. halotolerans / B. mojavensis & 100 \\
$\# 20$ & MT758465 & B. subtilis / B. tequilensis & 100 \\
$\# 21$ & MT758466 & B. halotolerans / B. mojavensis & 99.84 \\
$\# 22$ & MT758467 & B. subtilis / B. tequilensis & 100 \\
$\# 23$ & MT758468 & Paenibacillus polymyxa & 99.45 \\
\hline & BNCB &
\end{tabular}

*NCBI GenBank accession number 


\section{Table 5 (on next page)}

Enzymatic sensitivity and heat stability profile of antimicrobial activities

These 19 isolates showed antagonistic activities against Clostridium perfringens.

** Value indicates the diameter of the zone of antimicrobial activity in millimetres including well diameter of $6 \mathrm{~mm}$. - indicates no zone of clearing. Underlined enzyme indicated a loss of activity after enzymatic treatment. The values of temperature resistance were recorded after 3 hours of incubation. 
Table 4. Enzymatic sensitivity and heat stability profile of antimicrobial activities.

\begin{tabular}{|c|c|c|c|c|c|c|c|}
\hline Isolate & Activity* & Proteinase K (proK) & Pronase E (proE) & Trypsin & Lipase & Sensitive to enzymes & Resistant to $\left(\mathrm{t}^{\circ} \mathrm{C}\right)$ \\
\hline$\# 01$ & $13.67 \pm 0.58$ & $10.67 \pm 0.58$ & $10.67 \pm 0.58$ & 14.00 & $13.67 \pm 0.58$ & proE, proK & 60 \\
\hline$\# 02$ & 11.00 & 9.00 & - & $10.67 \pm 0.58$ & 11.00 & proE, proK & 60 \\
\hline \#04 & 9.00 & - & - & - & 9.00 & pProE, proK, trypsin & - \\
\hline \#05 & $23.67 \pm 0.58$ & $23.67 \pm 0.58$ & $23.67 \pm 0.58$ & $23.67 \pm 0.58$ & $23.67 \pm 0.58$ & - & 60 \\
\hline \#06 & $14.67 \pm 0.58$ & $13.00 \pm 1.00$ & $10.33 \pm 0.58$ & - & - & proE, trypsin, lipase & - \\
\hline \#08 & $13.67 \pm 0.58$ & 12.00 & $11.33 \pm 0.33$ & $13.33 \pm 0.33$ & 14.00 & proE, proK & 60 \\
\hline$\# 10$ & 9.00 & - & - & - & 9.00 & proE, proK, trypsin & - \\
\hline \#11 & 17.00 & 15.00 & - & $15 \pm 0.58$ & - & proE, proK, lipase & 60 \\
\hline \#12 & $11.67 \pm 0.58$ & $8.67 \pm 0.58$ & - & - & 12.00 & proE, proK, trypsin & - \\
\hline \#13 & 16.00 & 16.00 & 16.00 & $12.57 \pm 0.58$ & $18.33 \pm 0.58$ & trypsin & 60 \\
\hline \#14 & $8.67 \pm 0.58$ & $8.67 \pm 0.58$ & - & - & - & proE, proK, trypsin, lipase & - \\
\hline \#15 & $8.67 \pm 0.58$ & - & - & 9.00 & 9.00 & proE, trypsin & - \\
\hline$\# 16$ & $12.00 \pm 0.58$ & - & - & - & 12.00 & proE, proK, trypsin & - \\
\hline$\# 17$ & $12.33 \pm 0.58$ & $9.67 \pm 0.58$ & - & - & $8.67 \pm 0.58$ & proE, proK, trypsin & - \\
\hline \#18 & $9.67 \pm 0.58$ & $10.33 \pm 0.58$ & 10.00 & $10.33 \pm 0.58$ & 10.00 & - & - \\
\hline \#19 & $13.67 \pm 0.58$ & 14.00 & $13.67 \pm 0.58$ & $13.67 \pm 0.58$ & $12.67 \pm 0.58$ & - & 60 \\
\hline$\# 20$ & 11.00 & 11.00 & $8.67 \pm 0.58$ & 11.00 & 11.00 & proE & - \\
\hline \#21 & 15.00 & 11.00 & $12.33 \pm 0.58$ & 15.00 & $11.33 \pm 0.58$ & proE, proK, lipase & - \\
\hline \#23 & 13.00 & $12.33 \pm 0.58$ & - & $12.33 \pm 0.58$ & $12.67 \pm 0.58$ & proE & - \\
\hline
\end{tabular}

2 *: Value indicated the diameter of halo zone of antimicrobial activity in millimetres including well diameter of 6 mm. '-'indicates no zone of clearing.

3 Underlined enzyme indicated a loss of activity after enzymatic treatment. The values of temperature resistance were recorded after 3 hours of

4 incubation. The numbers in the table represented the mean value ( \pm standard deviation) of killing diameters from the measurement of three replicates.

5 These 19 isolates showed antagonistic activities against Clostridium perfringens. 


\section{Table 6(on next page)}

Antimicrobial activities amongst the short-listed isolates

The analysis was conducted using the cross-streak method.

+/++ zone of inhibition observed with clear halo of growth inhibition; - no inhibition. The species designations were assigned based on the 16S rRNA gene analysis in Table 3. 
1 Table 6. Antimicrobial activities amongst the short-listed isolates. The analysis was conducted using the cross-streak method.

\begin{tabular}{|c|c|c|c|c|c|c|c|c|c|c|c|c|c|c|c|c|c|c|c|c|c|c|c|}
\hline Isolate & $\# 02$ & $\# 04$ & $\# 05$ & $\# 12$ & $\# 14$ & $\# 16$ & $\# 17$ & $\# 18$ & $\# 20$ & $\# 22$ & $\# 06$ & $\# 08$ & $\# 11$ & $\# 13$ & $\# 15$ & $\# 07$ & $\# 09$ & $\# 03$ & $\# 10$ & $\# 01$ & $\# 19$ & $\# 21$ & $\# 23$ \\
\hline \#02 B. subtilis & - & - & - & - & - & - & - & - & - & - & - & + & - & - & - & - & + & - & - & - & - & - & - \\
\hline \#04 B. subtilis & - & - & - & - & - & - & - & - & - & - & - & + & - & - & - & - & - & - & - & - & - & - & - \\
\hline \#05 B. subtilis & + & + & - & + & - & + & + & + & + & + & + & + & + & + & + & + & + & + & + & - & - & + & + \\
\hline \#12 B. subtilis & - & - & - & - & - & - & - & - & - & - & - & & - & + & - & - & - & - & - & - & - & - & - \\
\hline \#14 B. subtilis & - & - & - & - & - & - & - & - & - & - & - & - & - & - & - & - & - & - & - & - & - & - & - \\
\hline \#16 B. subtilis & - & - & - & - & - & - & - & - & - & - & + & + & - & + & - & - & - & - & ++ & + & + & ++ & + \\
\hline \#17 B. subtilis & - & - & - & - & - & - & - & - & - & - & + & + & - & ++ & - & - & - & - & ++ & - & ++ & ++ & + \\
\hline \#18 B. subtilis & - & - & - & - & - & - & - & - & - & - & + & + & - & ++ & - & - & + & - & + & - & ++ & ++ & ++ \\
\hline \#20 B. subtilis & - & - & - & - & - & - & - & - & - & - & - & - & - & ++ & - & - & - & - & - & - & + & + & - \\
\hline \#22 B. subtilis & - & - & - & - & - & - & - & - & - & - & - & - & - & ++ & - & - & + & - & - & - & ++ & ++ & ++ \\
\hline \#06 B. amyloliquefaciens & + & + & + & + & - & ++ & ++ & ++ & ++ & ++ & - & + & + & + & - & + & + & + & + & + & ++ & ++ & ++ \\
\hline \#08 B. amyloliquefaciens & + & + & + & ++ & + & + & + & + & ++ & ++ & + & - & + & ++ & + & + & - & + & - & + & + & + & + \\
\hline \#11 B. amyloliquefaciens & - & - & - & - & - & - & - & - & - & - & - & - & - & - & - & - & - & - & + & - & - & - & - \\
\hline \#13 B. amyloliquefaciens & - & - & - & ++ & - & + & + & + & ++ & ++ & - & - & - & - & - & ++ & ++ & - & + & - & + & - & ++ \\
\hline \#15 B. amyloliquefaciens & - & - & - & - & - & - & - & - & - & - & - & - & - & - & - & - & - & - & + & - & - & - & - \\
\hline \#07 B. pacificus & - & - & - & - & - & - & - & - & - & - & - & - & - & - & - & - & - & - & + & - & - & - & - \\
\hline$\# 09$ B. pacificus & + & + & + & + & + & - & + & + & + & + & + & + & + & + & + & - & - & + & + & + & + & + & + \\
\hline \#03 B. licheniformis & + & + & + & + & ++ & ++ & ++ & ++ & ++ & ++ & + & + & + & ++ & + & + & + & - & + & + & ++ & ++ & + \\
\hline \#10 B. safensis & - & - & - & - & - & - & - & - & - & - & + & + & - & + & - & - & - & - & - & - & + & + & + \\
\hline \#01 B. halotolerans & + & + & - & + & + & + & + & + & + & + & + & + & + & + & + & + & + & ++ & + & - & - & + & + \\
\hline \#19 B. halotolerans & + & + & - & + & ++ & + & + & ++ & + & + & + & + & + & + & ++ & + & + & ++ & + & - & - & - & + \\
\hline \#21 B. halotolerans & - & - & - & + & - & - & + & + & + & + & - & - & - & - & + & + & + & - & - & - & - & - & - \\
\hline \#23 P. polymyxa & ++ & ++ & ++ & ++ & ++ & ++ & ++ & ++ & ++ & ++ & ++ & ++ & ++ & ++ & ++ & ++ & ++ & ++ & ++ & ++ & ++ & ++ & - \\
\hline
\end{tabular}

2

$3+/++$ zone of inhibition observed with clear halo of growth inhibition; - no inhibition. The species designations were assigned based on the $16 \mathrm{~S}$ 4 rRNA gene analysis in Table 3. 


\section{Table 7 (on next page)}

Characterization of short-listed bacterial isolates

+ ability to grow under conditions based on colon formation; ++ and +++ increased size of colonies on plates; and - absence of growth. For enzyme production the symbols indicate the relative sizes of the zones of activity. 


\section{Table 7. Characterization of short-listed bacterial isolates}

\begin{tabular}{|c|c|c|c|c|c|c|c|c|c|c|c|c|c|c|c|c|c|c|c|c|c|c|c|}
\hline Strains \# & $\# 01$ & $\# 02$ & $\# 03$ & $\# 04$ & $\# 05$ & $\# 06$ & $\# 07$ & $\# 08$ & $\# 09$ & $\# 10$ & $\# 11$ & $\# 12$ & $\# 13$ & $\# 14$ & $\# 15$ & $\# 16$ & $\# 17$ & $\# 18$ & $\# 19$ & $\# 20$ & $\# 21$ & $\# 22$ & $\# 23$ \\
\hline \multicolumn{24}{|c|}{ Salinity tolerance $(\mathrm{NaCl})$} \\
\hline $3 \%-5 \%$ & ++ & ++ & ++ & ++ & ++ & ++ & ++ & ++ & ++ & ++ & ++ & ++ & ++ & ++ & ++ & ++ & ++ & ++ & ++ & ++ & ++ & ++ & ++ \\
\hline $6 \%-7 \%$ & ++ & ++ & ++ & ++ & ++ & ++ & ++ & ++ & ++ & ++ & ++ & ++ & ++ & ++ & ++ & ++ & ++ & ++ & ++ & ++ & ++ & ++ & - \\
\hline $8 \%$ & ++ & ++ & + & ++ & ++ & + & - & + & ++ & ++ & ++ & ++ & ++ & ++ & ++ & ++ & ++ & ++ & ++ & ++ & ++ & + & - \\
\hline $9 \%$ & + & ++ & - & ++ & ++ & - & - & - & ++ & ++ & ++ & ++ & ++ & ++ & ++ & ++ & ++ & ++ & ++ & ++ & ++ & - & - \\
\hline $10 \%$ & - & + & - & + & + & - & - & - & + & + & + & + & + & + & + & + & + & + & ++ & + & + & - & - \\
\hline $12 \%$ & - & - & - & - & - & - & - & - & - & - & - & - & - & - & - & - & - & - & - & - & - & - & - \\
\hline \multicolumn{24}{|c|}{ Bile salt tolerance (mole/L) } \\
\hline $0.1 \mathrm{M}-0.7 \mathrm{M}$ & - & - & - & - & - & - & - & - & - & - & - & - & - & - & - & - & - & - & - & - & - & - & - \\
\hline \multicolumn{24}{|c|}{ Antibiotic susceptibility } \\
\hline Kanamycin & - & - & - & - & - & - & - & - & - & - & - & - & - & - & - & - & - & - & - & - & - & - & - \\
\hline Ampicillin & + & + & + & - & + & + & + & + & + & - & - & - & - & + & + & + & + & - & - & - & + & + & - \\
\hline Tetracycline & - & - & - & - & - & - & - & - & - & - & - & - & - & - & - & - & - & - & - & - & - & - & - \\
\hline \multicolumn{24}{|l|}{ pH tolerance } \\
\hline 5 & ++ & ++ & + & + & + & + & + & + & + & + & + & + & + & + & + & + & ++ & ++ & ++ & ++ & ++ & ++ & + \\
\hline $\begin{array}{l}6,7,8,9 \\
\text { Thermal toleranc }\end{array}$ & ++ & ++ & ++ & ++ & ++ & ++ & ++ & ++ & ++ & ++ & ++ & ++ & ++ & ++ & ++ & ++ & ++ & ++ & ++ & ++ & ++ & ++ & ++ \\
\hline $30^{\circ} \mathrm{C} ; 40^{\circ} \mathrm{C} ; 50^{\circ} \mathrm{C}$ & ++ & ++ & ++ & ++ & ++ & ++ & ++ & ++ & ++ & ++ & ++ & ++ & ++ & ++ & ++ & ++ & ++ & ++ & ++ & ++ & ++ & ++ & ++ \\
\hline \multicolumn{24}{|c|}{ Oxygen requirement for growth } \\
\hline Aerobic & ++ & ++ & ++ & ++ & ++ & ++ & ++ & ++ & ++ & ++ & ++ & ++ & ++ & ++ & ++ & ++ & ++ & ++ & ++ & ++ & ++ & ++ & ++ \\
\hline Microaerophillic & ++ & ++ & ++ & ++ & ++ & ++ & ++ & ++ & ++ & ++ & ++ & ++ & ++ & ++ & ++ & ++ & ++ & ++ & ++ & ++ & ++ & ++ & ++ \\
\hline Anaerobic & - & - & - & - & - & - & - & - & - & - & - & - & - & - & - & - & - & - & - & - & - & - & - \\
\hline \multicolumn{24}{|c|}{ Enzyme production } \\
\hline Protease & +++ & + & - & + & - & +++ & + & ++ & ++ & + & + & + & ++ & - & + & + & ++ & ++ & +++ & - & ++ & + & ++ \\
\hline Cellulase & ++ & ++ & ++ & ++ & ++ & ++ & + & ++ & + & - & ++ & ++ & ++ & ++ & ++ & ++ & ++ & ++ & ++ & - & - & ++ & ++ \\
\hline Amylase & + & + & - & + & + & + & + & + & + & - & + & + & + & + & + & + & + & + & + & + & + & + & + \\
\hline
\end{tabular}

2

$3+$ ability to grow under conditions based on colon formation; ++ and +++ increased size of colonies on plates; and - absence of growth. For enzyme

4 production the symbols indicate the relative sizes of the zones of activity. 


\section{Figure 1}

Morphological diversity of the marine isolates.

Colony morphologies of some pure marine spore- forming bacteria. The symbol \# indicated the isolate number amongst the 23 short-listed isolates. ' $C$ ' is an example of a primary culture plate, in this case from a seaweed sample, from which isolates were subsequently colony purified. Photo credit: Chau Minh Khanh. 


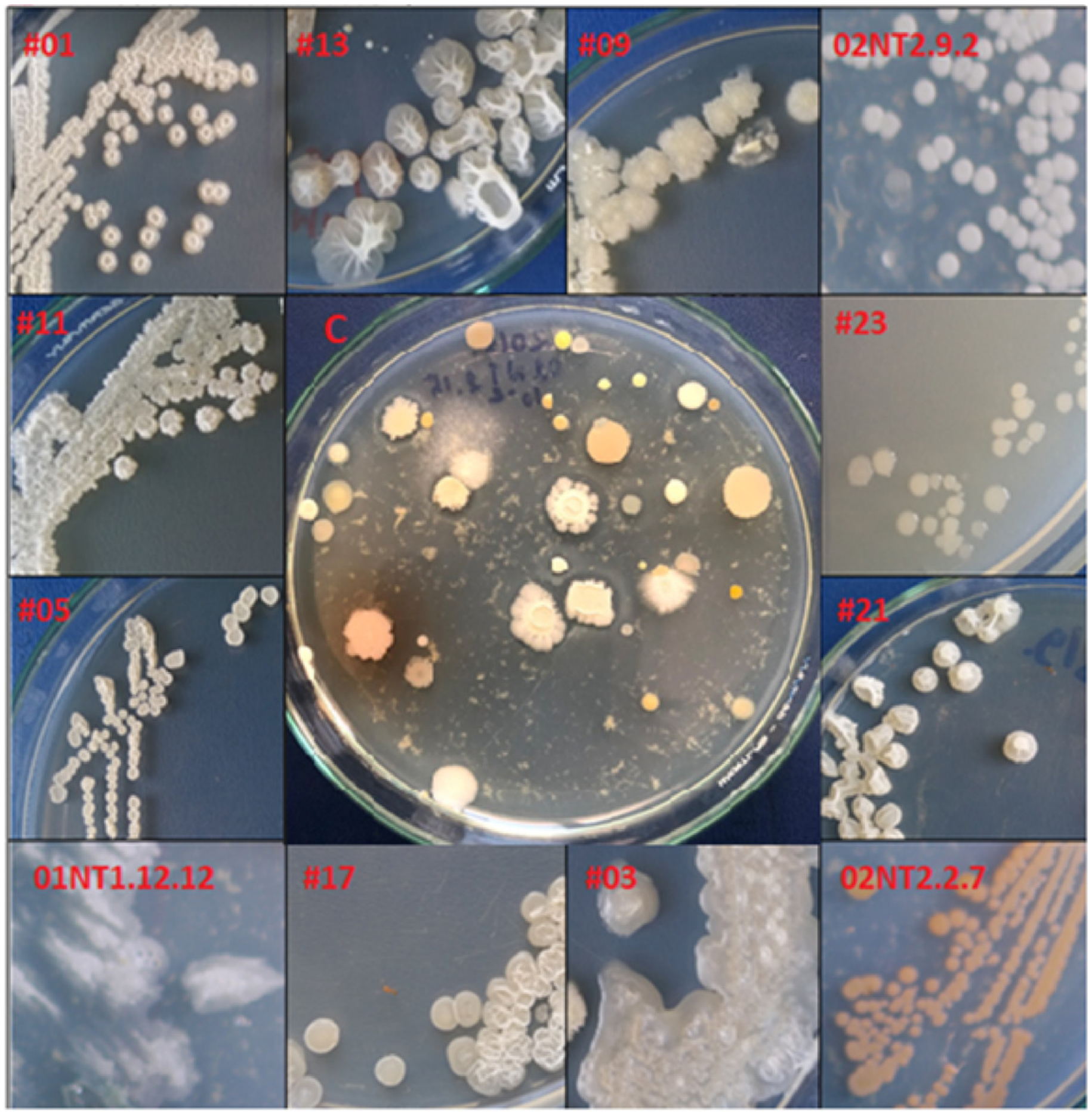




\section{Figure 2}

Bioactivity assays.

Antimicrobials activity screened by (A, B) cross-streak assay and (C) well-diffusion assay. (A) The cross-streak assay to identify antimicrobial producing bacteria against 6 indicators including; (1) S. faecalis; (2) B. cereus; (3) P. aeruginosa; (4) E. coli; (5) S. aureus; (6) C. albicans. (B) The illustration of cross-activity exhibited by $P$. polymyxa \#23 (as a representative) against growth of other marine species. Notably, $P$. polymyxa killed all other marine Bacillus excepting itself \#23 (as negative control). (C) The growth of MRSA as indictor was depressed by two isolates' culture supernatants. (D) Proteolytic activity screened on skim milk agar. (E) Cellulose degradation activity screened on CMC agar. (E) Amylase production screened on starch agar. Photo credit: Chau Minh Khanh. 


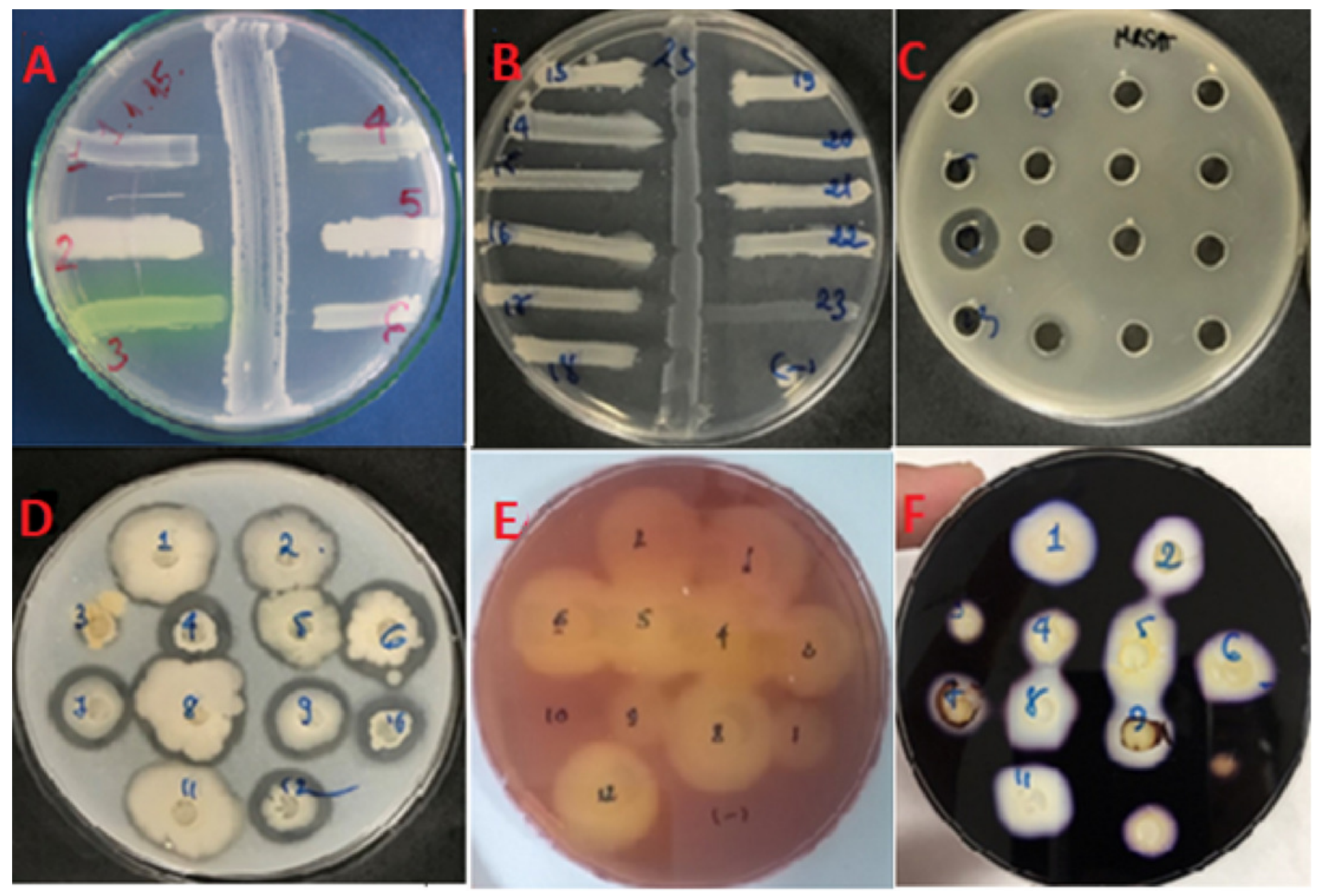


Figure 3

Antimicrobial activities amongst the short-listed 23 isolates against 14 pathogenic indicator strains.

Chart was constructed based on the value obtained from Table 5. WD: Well-diffusion assay, CS: Cross-streak assay. 


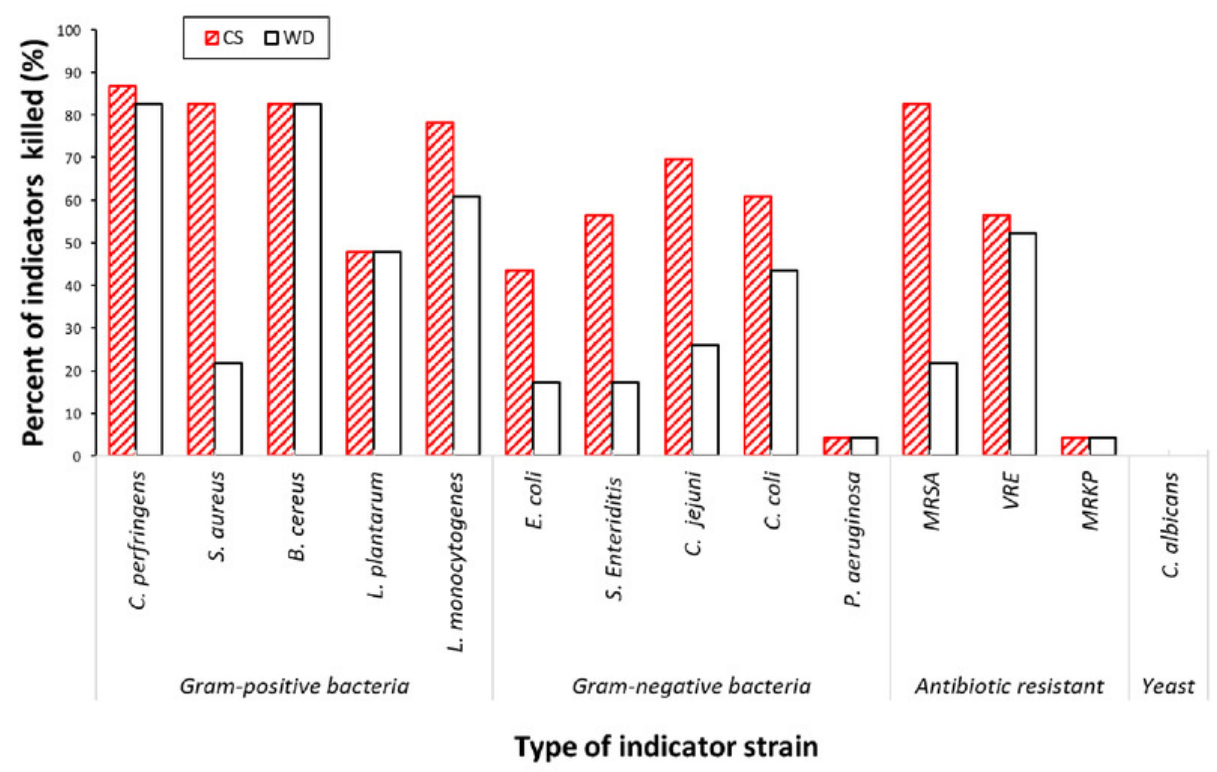




\section{Figure 4}

Phylogenetic tree of the short-listed 23 antimicrobial producing isolates.

The neighbor-joining phylogenetic tree was constructed using the maximum composite likelihood method, bootstrap method of 1000 replication and pairwise deletion by MEGA 7. In this tree, 23 marine isolates were displayed by number value, while all reference strains bacteria were closely related bacteria identified and downloaded from NCBI. 


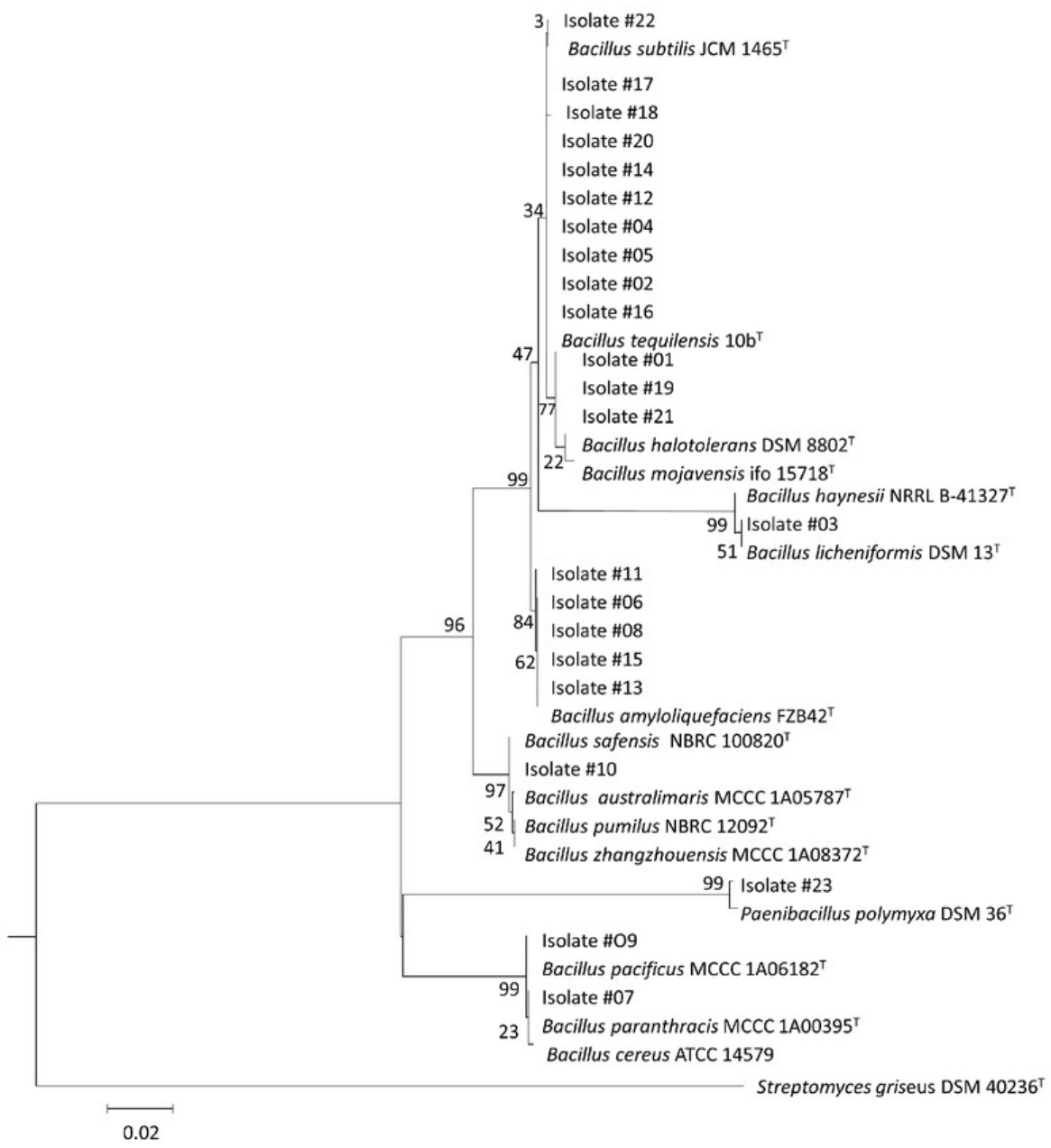

